\title{
直腸癌局所再発例に対する放射線治療の経験
}

一小腸被爆防止のための一工夫一

\begin{tabular}{llllll}
\multicolumn{8}{c}{ 滋賀医科大学第 2 外科 } & \\
山本 & 明 & 藤村 & 昌樹 & 平野 & 正満 \\
佐藤 & 功 & 新屋 & 久幸 & 馬場 & 裕司 \\
西沢 & 弘泰 & 和田 & 道彦 & 岡田 & 慶夫
\end{tabular}

\section{A CASE REPORT OF IRRADIATION FOR RECURRENT RECTAL CANCER IN THE PELVIS -A SURGICAL DEVICE TO PREVENT SMALL INTESTINE FROM THE EXPOSURE-}

\author{
Akira YAMAMOTO, Masaki FUJIMURA, Masamitsu HIRANO, \\ Isao SATO, Yuji BABA, Hiroyasu NISHIZAWA, \\ Michihiko WADA and Yoshio OKADA
}

2nd Department of Surgery, Shiga University of Medical Science

卖引用語：直腸癌局所再発, 骨盤腔放射線治療, 小腸被爆防止

はじめに

最近, 私どあは直腸癌局所再発例に対し, 残存骨盤 内臓全摘術に加之, 術後の放射線治療に際し, 小腸の 被爆をまぬがれるべき工夫を施し, 目的線量を合併症 もなく照射完了し, 現在経過良好な症例を経験したの で報告する。

\section{症例}

患者：26歳，女性，保母.

主訴: 心窩部痛, 呕気, 腰背部鈍痛.

既往歴： 7 年前, 直腸癌で直腸切断術を受けた ${ }^{1)} .1$ 年前，腎責炎で加療された。

現病歴： 7 年前, 直腸癌 ( $\mathrm{RbRa}, \mathrm{ss}, \mathrm{ai}, \mathrm{n}_{1}, \mathrm{H}_{0}$,

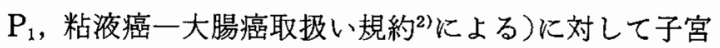
附属器合併切除を含む直腸切断術を施行され, 近医で 経過観察されていた。61年 4 月心窩部痛, 呕気を訴え 来院. 胃内視鏡検査で出血性びらん性胃炎を認めた。 その時の血液検查で carcino embryonic antigen（以 下 CEA)が $53 \mathrm{ng} / \mathrm{ml}$ と高値を示したため, 腹部超音波 検査を施行したところ, 右腎需の抎張がみられた。こ のため直腸癌の局所再発が疑われ, 精査治療の目的で 入院した。

入院時現症：栄養状態は中等, 眼䀫結膜および眼䀫 結膜に貧血, 黄㾝は認めない。表在リンパ節, 肝, 脾,

$<1988$ 年 1 月13日受理 $>$ 別刷請求先：山本 明

于520-21 大津市瀬田月輪町 滋賀医科大学第 2 外科
左堅は触知しないが，右堅下極を触知し，軽度圧痛を 認める。人工肛門部, 会陰部手術創瘢痕に著変を認め ない.

入院時検查成績 : CEA が46.3ng/ml と異常を示す 以外, 一般検血, 血液生化学検査, その他腫瘍マ一カー などに異常は認めない.

腹部 computed tomograpy (CT) 所見: 肝転移, リ ンパ節腫大などは認めない. 右腎监, 右尿管の㹡張と, 第 4，5仙骨前面やや右側よりに, enhancementされ る鶏卵大の腫瘤を認める(図 1 ).

腹部血管造影所見：腫晸は，右子宮動脈根部付近か らの新生血管の支配をらけ，軽度血管増生を示す（図 2).

以上の所見から, 直腸癌の局所再発による右尿管の 閉塞と診断し，6月26日，再切除を目的に開腹手術を 施行した.

開腹所見と術式：肝転移，腹膜播種，腹水は認めな い, 再発腫瘤は, 回腸, 左右尿管, 膀胱後壁および仙 骨前面に浸潤痖着し, 直接露出はしていない.これら を一塊として切除し,さらに骨盤壁への浸潤部に対し 摘出を試みたが，仙骨方向への浸潤が強固で出血量も 増大した. 仙骨合併切除以外摘出不能と考え, 一部遺 残せざるを得ないと判断した。 そこで腫瘍遺残部に対 する術後放射線治療を企図し, 下腹部前腹壁の腹膜, 腹直筋後䩗, 横筋々膜を剩離して, flapを作成した。 そ してそれを用いて左右腸骨稜と仙骨岬を結ぶ線で隔壁 
図 1 腹部 CT 所見. 上：右腎盘, 尿管の拡張を示す。 下：仙骨前面の enhancementされる鷄卵大腫瘤を 示す.
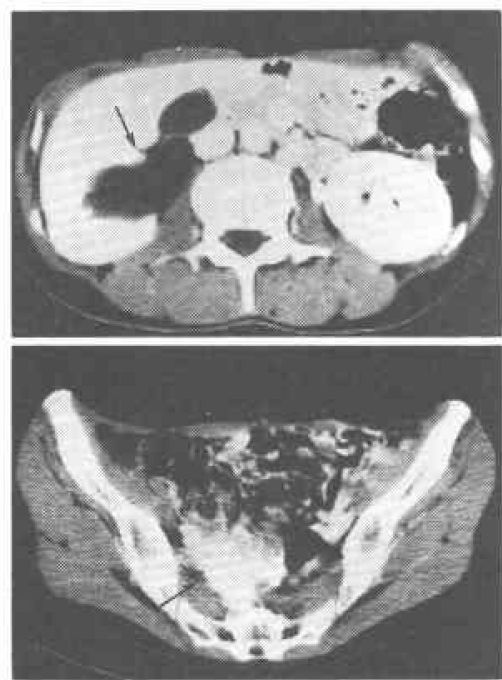

図 2 腹部血管造影所見. 右子宮動脈根部付近で血管 の新生と増生がみられる。

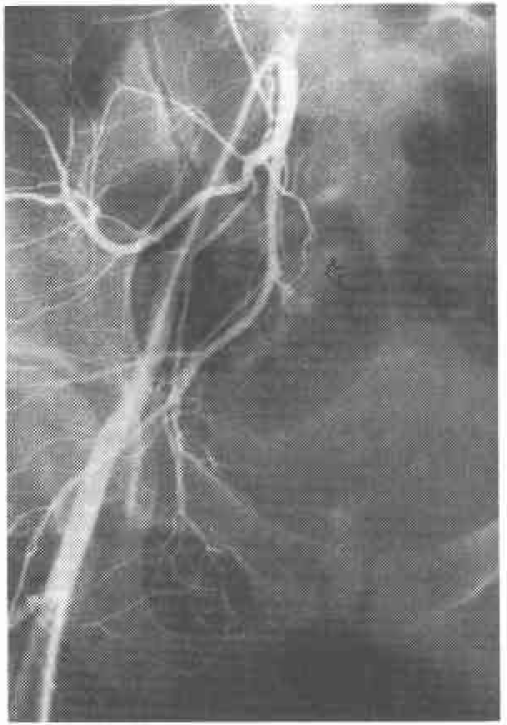

となし，小腸の骨盤腔への落ち込み防止の措置とした (図 3，4）。さらに腟断端を開放し，内照射の直接到 達経路とした。回腸導管を右下腹部に造設し, 手術を 終了した.

切除標本所見：再発腫瘍は，回腸を 3 カ所で，そし て膀胱扣よび両側尿管をまき込み浸潤している（図 5 ).
図 3 術中写真. 下腹部前腹壁の腹膜・筋膜を剝離し て作成した隔壁を示す。

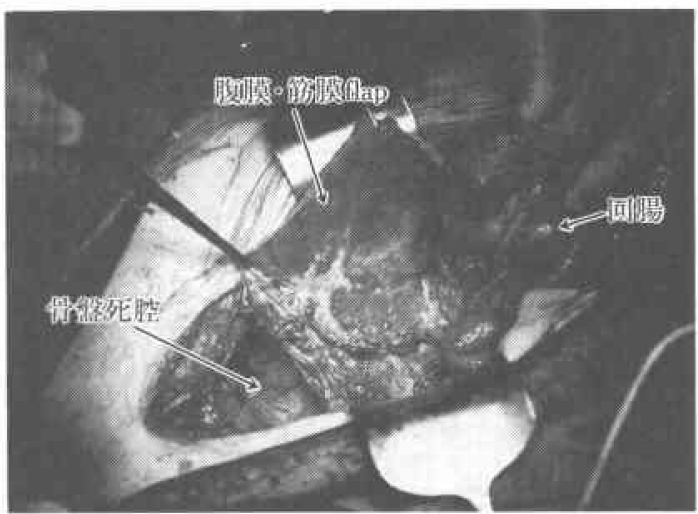

図 4 小腸の落ち込み防止隔壁作成の模式図. 1. 前腹 壁の腹膜・筋膜を剝離する，2，左右の flap を縫合 乙，後腹壁に縫着寸る．3，隔壁の完成(正中矢状断)
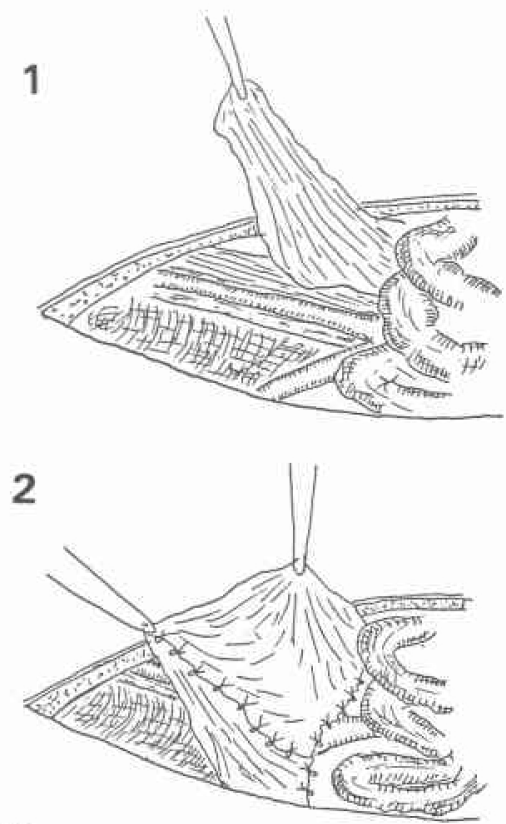

3

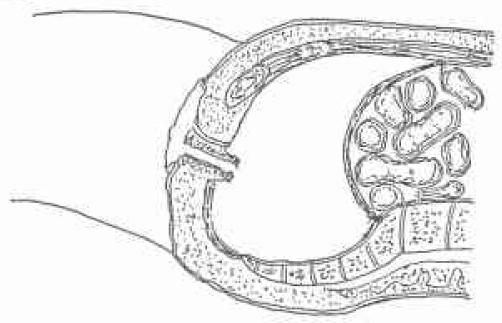


図 5 切除標本. 図の中央は腫瘍・膀脱底部および尿 管を,左右および下方は合併切除された回腸を示す。

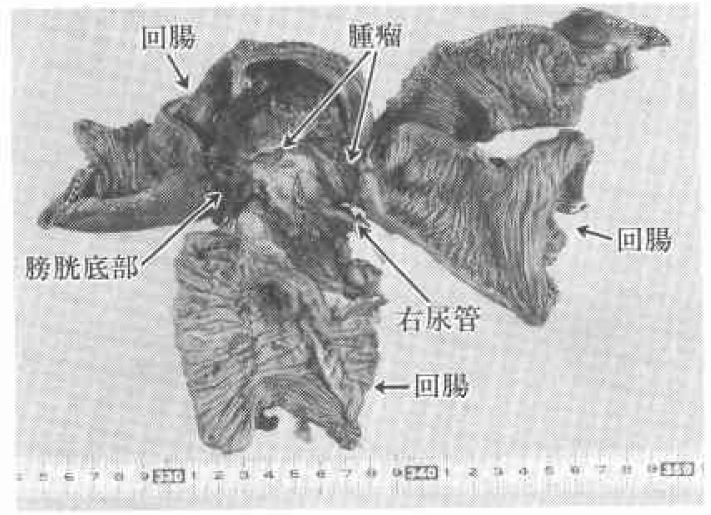

図 6 病理組織所見. 著明な結合織の増生と円形細胞 の浸潤および散在する腫崵細胞を示す。

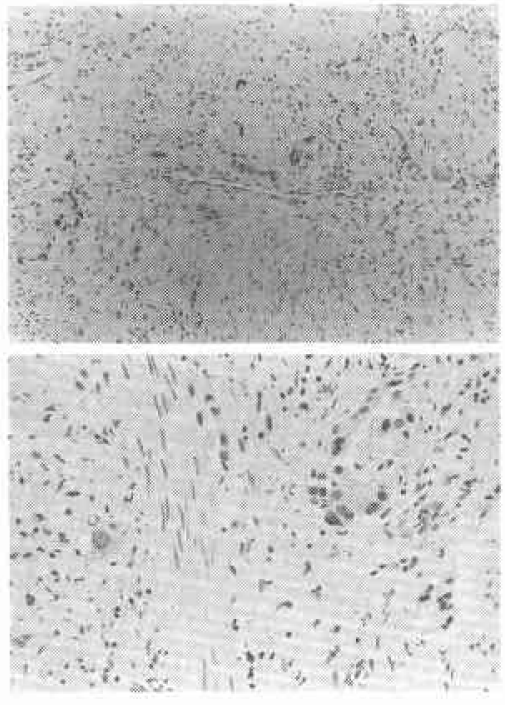

病理組織所見：結合織の増生と円形細胞の浸潤がめ だち,そのなかに腫瘍細胞が散在してみられる(図6).

術後経過: 術後10日目から SengstakenBlakemore-tube のバルーンを利用した経胵的内照射 (RALS)を, 照射野をしぼった外照射と併用し, 計 6000 $\operatorname{Rad}$ の目的治療線量を照射した(図 7). 術前高值を示 したCEA は，12日目で4.9ng/mlに低下し，さらに50 日目で $1.7 \mathrm{ng} / \mathrm{ml}$ と正常化した。術後 1 年余を経過し た現在，骨盤腔はなお手挙大の死腔を残している，最 近の経胵的内視鏡観察では, 最も多くの線量が照射さ れた腫瘍遺残部は肉芽増生が悪く, 一部で仙骨靱帯の 露出がみられる。遺残局所の生検で腫瘍細胞は認めら
図 7 形成された骨盤死腔と Sengstaken-Blakemore-tubeのバルーンを利用した内照射を示す。

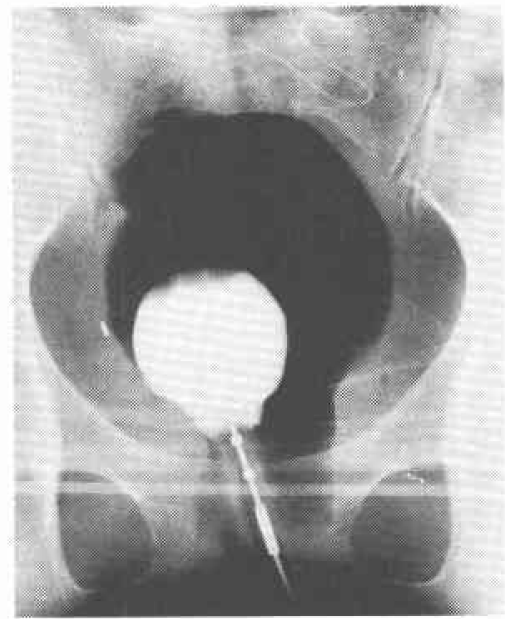

れず，経過良好である。

\section{考察}

直腸癌の術後遠隔時再発は, 肝転移々局所再発でそ の大部分を占めるとされる ${ }^{344)}$. 肝転移に対しては積極 的な転移巣切除や, 動注化学療法などが施行され, そ の有效性が報告されている。しかし再発率 3 -37\%を 示し4)最も多いとされる局所再発では，その早期発見 が困難で, CT, 超音波検査などを駆使しても再発か否 かの確診が困難な例も多いとされる5)6). そして診断さ れた時点では再切除不能例や，残存骨盤内葴全摘術に よっても腫場遺残のみられる例も多く, それらには化 学療法や放射線治療が行われている。 また仙骨浸潤例 では, 仙骨合併骨盤内葴器全摘術という超拡大手術が 試行されてはいるが，いまだ一般的とはいえないて99. しかし，再発例とはい点，手術を含むいわゆる集学的 治療により，その予後の改善が得られることも確かで あるとされる10).

自験例は，初回手術時すでに腹膜転移や子宮，卵宩 への転移を認めたが，その合併切除によりすでに 7 年 余の生存が得られて扣り，「治癒」を想起させる時期で の再発であった。そして，びらん性胃炎による胃痛を 契機に来院し, CEAの高值と水堅症のため容易に骨盤 腔再発が推測でき，比較的早期に局所再発の診断がな されたと思われる。それでも単なる残存骨盤内葴器の 全切除のみでは骨盤壁に腫㾴の遺残がみられた。この ことは，長期経過例においても，画像診断，血清診断 を駆使した定期的な検査の必要性と，そのような再発 チェックによってしか, 再切除施行の可能性が得られ ないことを示している。また本例では，血清 CEA の変 
動が腫痬の存在の明瞭な指標となり, 腫瘍マーカーの 有用性が再確認された。

一方，骨盤腔放射線治療は婦人科領域で汎用され， また直腸癌に対しても集学的治療の一手段として術 前, 術後に施行されている ${ }^{111}$.

しかし，骨盤腔への放射線照射は，単に早期障害と しての放射線性腸炎による下㢉などにとどをらず， 1 ～2\%から $20 \%$ と報告により差はあるものの，3 月月 から 10 年の経過の後に晚期障害としての腸閉塞や難治 性瘦孔形成をひき抗こし, 治療に難渋する例も決して 稀ではない12)。そのため, 骨盤腔への放射線治療には, 小腸の被爆防止を中心とした合併症防止の努力が必須 であるとされる13).

私どもも, 子宮頸癌に対する放射線治療により生じ た腸閉塞や複雑難治な瘦孔形成例に対する治療経験か ら, 放射線治療の意義は認めつつ, 放射線障害による 合併症対策の重要性を痛感してきた。そのため本報告 例で, 術後放射線治療を企図した際にも，小腸の被爆 防止を最優先させるべきと考えた。

今日までにも小腸の放射線障害を指摘警告する論文 はみられるが, 被爆防止のための具体的な工夫に関寸 るものは決して多くはない. Green らは腹臥位, 骨盤 高位で照射することを推奖し ${ }^{14)}$, Cohen らは術中 clippingによる照射野の限定, 大網による pedicle-flap の 作成, 拡張膀脱の利用などの工夫をあげ15), 森谷らはバ ルーン, 骨盤内死腔形成, 皮膚筋弁に上る充填などの 対策をあげている10). また Hoskinsらは multiplefield-techniques と bladder-distensionによって小腸 の合併症の増加はなかったとしている16).

自験例のような骨盤内臓器全摘例では, 何らかの工 夫なしには，骨盤空への小腸の落ち込みは防止しえず, 小腸の被爆は免がれえない。私どもの施行した前腹壁 を利用しての隔壁形成は特別な手技を必要とせず，腹 膜とともに前腹壁筋膜を豩離し, 照射野を考慮に入れ, 死腔の大ささに応じて骨盤後壁に縫着するのみであ る.これにより照射野は完全に骨盤死腔内に限定され， 小腸の被爆は皆無であった。 また膣断端を開放したこ とは，単に死空からの分泌物の排泄路としてだけでな く, 内照射の併用, 経腔的内視鏡観察, および生検施 行を可能にした。これらの手技は，初回手術時におい ても, 切除不能例や局所遺残例で, 放射線治療を企図 する際には，試みられるべき術式と考えられる。
まとめ

直腸癌局所再発例に対する再切除に際し，腫鹗遺残 部への放射線治療および経過観察のため，前腹壁を利 用した隔壁形成と腔断端開放を行い，きわめて有効で あったので報告した。

\section{文 献}

1) 山本 明, 肥後昌五郎, 平野正満汪か：19歳直腸癌 の 1 例と本邦若年者例の検討. 日消外会誌 14 ： $1108-1112,1981$

2）大腸癌研究会編：臨床・病理・大腸癌取扱い規約. 3 版. 金原出版, 東京, 1983

3）土屋周二, 大木繁男, 大見良裕任か：再発形式から みた再発大腸癌の治療方針. 消外 $8: 1207-$ 1210,1985

4）安富正幸, 西山真一,八田昌樹活か：局所括よび吻 合部再発の予防と治療. 消外 $8: 1215-1221$, 1985

5）原英, 木戸長一郎, 遠藤登喜子：直腸癌の局所 再発とCT. 日本大腸肛門病会誌 $37: 551-556$, 1984

6) 谷山新次, 斉藤典男, 更科広実注加：体腔内走查超 音波検查法により早期診断された直腸癌局所再発 の 1 治験例. 千葉医誌 $62: 103-107,1986$

7) 前谷俊三, 飯島康介,内藤厚司ほか：骨盤内缄と骨 盤壁の抎大合併切除。手術 $38: 637-644,1984$

8）高木 弘, 森本剛史, 加藤知行ほか：進行および局 所再発直腸癌に対する骨盤内䁍器全摘出術につい て。癌の臨 $30: 1779-1785,1984$

9）森谷冝皓, 小山靖夫, 北條慶一活加：進行直晹癌的 よび局所再発直腸癌に対する仙骨合併骨盤内臓器 全摘術. 日本大晹肛門病会誌 $38: 7-15,1985$

10）森谷冝皓, 小山靖夫, 北條慶一ほか：進行大腸癌汇 対する集学的治療. 日消外会誌 $16: 1847-1851$, 1983

11）水沢広和, 高橋俊雄：直腸癌術後局所再発防止を 目的とした集学的治療.日消外会誌 $16: 1852$ $-1855,1983$

12）堀江良秋，三島好雄，原宏介海加：放射線治療後 の消化管障害について.外科 $37: 261-269,1975$

13）山田明義, 佐々 木宏晃, 大森尚文注加: 放射線腸管 障害。癌の臨 $26: 996-1004,1980$

14) Green N, Iba G, Smith WR: Measures to minimize small intestine injury in the irradiated pelvis. Cancer $35: 1633-1640,1975$

15) Cohen AM, Gunderson LL, Welch CE: Radiation therapy of rectal cancer. World J Surg 6 : $560-568,1982$

16) Hoskins RB, Gunderson LL, Dosoretz DE et al: Adjuvant post operative radiotherapy in carcinoma of the rectum and rectosigmoid. Cancer $55: 61-71,1985$ 